\title{
Bilge International Journal of Science and Technology Research
}

Web : http://dergipark.gov.tr/bilgesci - E-mail: kutbilgescience@gmail.com

Received: 24.02 .2018

Accepted: 14.03 .2018

DOI: $10.30516 /$ bilgesci.398334

ISSN: $2587-0742$

e-ISSN: $2587-1749$

2(1), 31-39, 2018

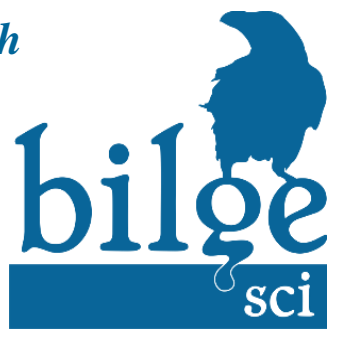

\section{Changes in Quality Parameters of Deep Fat Fried Carrot Slices Under the Effect of Ultrasound Assisted Pre-drying Process}

Merve Secil Turan ${ }^{1 *}$, Erkan Karacabey ${ }^{1}$

\begin{abstract}
Oil absorption is partially associated to the initial moisture content of frying material, thus controlling the moisture level could result in decreased oil absorption during frying with accompanying changes in other physical properties. As a result, in the current study, in order to figure out the changes in moisture and oil contents of fried carrot slices, the effects of process parameters of ultrasound (U/S) assisted pre-drying was examined. As process conditions of U/S, power levels of $30 \%, 50 \%$, and $70 \%$, temperature levels of 30 and $50{ }^{\circ} \mathrm{C}$, and time periods of 5, 10 and $15 \mathrm{~min}$ were studied. Additionally texture and color preferences were studied. Any reduction in oil absorption was achieved by U/S-predrying, whereas it was observed that there was an increase in brightness $\left(\mathrm{L}^{*}\right)$ value of carrot slices as well as generally a decrease in $\mathrm{a}^{*}$ values compared to the control group (directly deep-fat-fried $4 \mathrm{~mm}$-carrot slices at $160^{\circ} \mathrm{C}$ for 120 seconds). Effect of temperature was found to be significant over $\mathrm{a}^{*}$ and $\mathrm{L}^{*}$ values for all power levels. Additionally, no statistically significant change was observed for the textural properties with applied ultrasound power levels.
\end{abstract}

Keywords: frying; food drying; texture; oils; color.

\section{Introduction}

Frying is a common cooking method with a wide range of applications all over the world. In the frying process, product is immersed in pre-heated oil at certain temperature level being far above the boiling point of water. Thus, water movement throughout the solid matrix occurs with accompanying oil absorption and product is removed from oil, when color and textural characteristics meet the sensorial expectations (Gupta, 2005; Dueik et al., 2010; Medina et al., 2015; Esturk et al., 2000). This oil absorption is crucial parameter, since high amount of fat intake is known to potentially cause disorders such as coronary heart disease, diabetes (Saguy and Dana, 2003). Therefore, people are willing to consume low-fat products (Esturk et al., 2000). Studies show that reduction in moisture content encourages positively oil absorption and final product has high oil content which could be potentially hazard for health (Pedreschi and Moyano, 2005; Krokida et al., 2001; Moreira et al.,
1999; Vitrac, 2000; Lamberg et al., 1990; Moreira et al., 1997). Consequently, many techniques to apply before frying have been developed in food industry such as; drying (Pedreschi and Moyano, 2005), microwave drying (Gamble and Rice, 1987), vacuum assisted microwave drying (Song et al., 2007), vacuum frying (Dueik et al., 2010), osmotic dehydration (Ikoko and Kuri, 2007), application of coating material (García et al., 2004; Esturk et al., 2000; Lalam et al., 2013).

In literature there are a plenty number of research works about potato chips being pre-dried with different techniques before frying. However, there is no any literature focusing on the ultrasound assisted hot air pre-drying prior to deep fat frying for fried carrot slice manufacturing.

In reported studies, improvements in drying characteristics of different plant materials have been achieved by ultrasound assisted drying technique as a result of the sponge effect occurring in micro channels (Garcia-Perez et al., 2007;
${ }^{1}$ Suleyman Demirel University, Engineering Faculty, Food

Engineering Department, 32260, Isparta, Turkey.

*Corresponding author: erkankaracabey@ sdu.edu.tr
Citation: Turan, M.S., Karacabey, E. (2018). Changes in Quality Parameters of Deep Fat Fried Carrot Slices Under the Effect of Ultrasound Assisted Pre-drying Process. Bilge International Journal of Science and Technology Research, 2 (1): 31-39. 
Ortuño et al., 2010; Nowacka et al., 2012). Therefore, with sonication, it was supposed to achieve a reduction in moisture content and also oil absorption.

In this study, it was aimed to facilitate drying characteristics by means of the effect of ultrasound application, as a result, to achieve the encouraged moisture movement throughout the carrot slices during drying. Additionally, the influences of ultrasound assisted pre-drying and frying of carrot slices on the quality parameters like color and texture values were examined.

\section{Material and Method}

\subsection{Sample preparation}

Carrots (Daucus carota L. subsp. Sativus, Nanco) were purchased five days after the harvest from a local market in Isparta, Turkey, and were stored in a polyethylene bags in a refrigerator at $4^{\circ} \mathrm{C}$ before use. Initial moisture content of carrot samples were determined as $897.0 \pm 2.0 \mathrm{~g} \cdot \mathrm{kg}^{-1}$, which was coincidence with the range $\left(873-910 \mathrm{~g} \cdot \mathrm{kg}^{-1}\right)$ reported by Gichuhi et al. (2009). Before the analyses, carrot was washed, cleaned and peeled. Peeled carrots were sliced at $4 \mathrm{~mm}$ thickness using an industrial type slicer (Arisco, HBS-200, Turkey). Carrot slices having diameter of $2.5 \pm 0.5$ $\mathrm{cm}$ were selected for remaining process steps. Afterwards, carrot slices were subjected to blanching for $90 \mathrm{~s}$ in a hot water at $85^{\circ} \mathrm{C}$ and then cooled down using tap water for 120 seconds. Excess surface water was removed using absorbent paper.

\subsection{Ultrasound pretreatments and hot air drying}

Boiled carrot slices have been immersed in a beaker filled with distilled water. Sonication was conducted by using an ultrasonic probe having ultrasonic frequency of $20 \mathrm{kHz}$ and density of 500 W. $\mathrm{m}^{-2}$ (Ultrasonic-Homogenizer, Cy-500, Spain). The ratio of sample in water for all groups was adjusted 1: $4(\mathrm{w} / \mathrm{v})$ in order to avoid environment effect on sonication influence (Fernandes et al., 2006). Ultrasonic treatments were carried out at power levels of $30 \%, 50 \%$, and $70 \%$ under temperature levels of 30 and $50{ }^{\circ} \mathrm{C}$ for time periods of 5, 10 and $15 \mathrm{~min}$. All conducted trials and relevant process conditions were given in Table 1.
A bunch of carrot slices ( $50 \mathrm{~g})$ of previously pretreated by ultrasound (at different temperature, time and power) were arranged as a single layer on a tray and dried in a convectional hot air dryer (Mikrotest, MKD, Turkey) at air flow rate of $1.3 \pm$ $0.02 \mathrm{~m} \mathrm{~s}^{-1}$. Temperature and weight loss during drying were set according to optimal drying conditions $\left(63.4^{\circ} \mathrm{C}\right.$ for drying temperature, $16 \%$ for weight loss during drying) determined in our previous study (Karacabey et al., 2016).

Table 1. Ultrasonic Pretreatments

\begin{tabular}{llll}
\hline Label & $\begin{array}{l}\text { Power } \\
(\%)\end{array}$ & $\begin{array}{l}\text { Temperature } \\
\left({ }^{\circ} \mathrm{C}\right)\end{array}$ & $\begin{array}{l}\text { Time } \\
(\mathrm{min})\end{array}$ \\
\hline $\mathrm{A}$ & 50 & 30 & 5 \\
$\mathrm{~B}$ & 50 & 30 & 10 \\
$\mathrm{C}$ & 50 & 30 & 15 \\
$\mathrm{D}$ & 50 & 50 & 5 \\
$\mathrm{E}$ & 50 & 50 & 10 \\
$\mathrm{~F}$ & 50 & 50 & 15 \\
$\mathrm{G}$ & 30 & 30 & 15 \\
$\mathrm{H}$ & 50 & 30 & 15 \\
$\mathrm{I}$ & 70 & 30 & 15 \\
\hline
\end{tabular}

\subsection{Deep fat frying}

When the target weight loss on samples was attained, frying was conducted using $3 \mathrm{~L}$ of sunflower oil (Marsa Oil Industry Co. Ltd., İstanbul, Turkey) in an industrial type fryer (Remta Co. Ltd, İstanbul, Turkey) under specified optimal conditions determined as $152^{\circ} \mathrm{C}$ for frying temperature, and $207 \mathrm{~s}$ for frying time (Karacabey et al., 2016).

After frying, the fried carrot slices were removed from the oil and drained for about $300 \mathrm{~s}$ over a wire screen to drain the most of the surface oil, and then the slices were transferred to an absorbent towel. Frying oil was replaced with fresh one, after each run was completed. In order to determine the reference values for untreated samples, one group of carrot slices were directly fried after blanching without pre-treatment steps. Oil content, moisture content, breaking force, and $\mathrm{L}^{*}, \mathrm{a}^{*}, \mathrm{~b}^{*}$ value were measured in these fried slices. Temperature $\left(160^{\circ} \mathrm{C}\right)$ and time $(120$ sec. $)$ were the corresponding values of directly deep-fat-frying process which was determined according to our previous study. In that study, sensory analysis was conducted to determine the process conditions, fried carrot slices (4 mm thickness) at which took the highest score. Texture values, $\mathrm{L}^{*}, \mathrm{a}^{*}$, and $\mathrm{b}^{*}$, 
oil content and moisture content of control group is shown in Table 2.

\subsection{Analyses of samples}

\section{Moisture content}

The method of Fan, Zhang was used (Fan et al., 2005). Carrot slices were ground after frying. Five gram of ground samples were used for moisture content $\left(\mathrm{g}^{\mathrm{kg}} \mathrm{kg}^{-1}\right)$. Ground samples were dried in an oven (FN300, Nuve, Turkey) at $105 \pm 0.5^{\circ} \mathrm{C}$, until no weight change was attained. Test was performed in duplicate.

Table 2. The Results of Control Group

\begin{tabular}{ccccccc}
\hline \multirow{2}{*}{$\mathrm{MC}, \%$} & $\mathrm{OC}^{*} \%$ & $\mathrm{~L} *$ & $\mathrm{CV}$ & \multicolumn{3}{c}{$\mathrm{TP}$} \\
\cline { 3 - 7 } & & $\mathrm{L} *$ & $\mathrm{a}^{*}$ & $\begin{array}{c}\mathrm{H}, \mathrm{g} \\
\text { force }\end{array}$ & $\begin{array}{c}\mathrm{BF}, \mathrm{g} \\
\text { force }\end{array}$ \\
\hline 48 & 32.50 & 50.3 & 30.4 & 41.8 & 462.8 & 549.0
\end{tabular}

${ }^{*}$ Oil content (\%) is calculated based on the dry weight. MC: moisture content; OC: Oil content; CV: Color values; TP:

Texture properties; H: Hardness; BF: Breaking force

\section{Oil content}

The oil determination method reported by Sulaeman et al. (2001) was used with modification. Briefly, oil extraction was performed in a Soxhlet extractor (Büchi Universal Extraction System B-811, Germany) using hexane as a solvent to determine the oil content of fried carrot slices. Before extraction, fried samples $(5 \mathrm{~g})$ were dried in a vacuum oven and then ground (James, 1998). Oil content (g.kg-1) was calculated as wet bases. The test was performed in duplicate.

\section{Surface Color}

Color parameters $\left(\mathrm{L}^{*}, \mathrm{a}^{*}\right.$, and $\left.\mathrm{b}^{*}\right)$ were measured using a colorimeter (NH310, 3nh Tech. Co., Ltd. China) (Robertson, 1977). The equipment was standardized each time with white and black references. Five carrot slices and at five different locations for each slice were used for color measurements and mean values were reported.

\section{Texture Values}

Texture analysis was conducted by a texture analyzer (TA.XT Plus, Stable Micro System Co. Ltd., Godalming, UK). The PS / 30 probe and LKB probe were used to measure the slice hardness and firmness, respectively. PS / 30 probe movement speed was $1 \times 10^{-3} \mathrm{~m} \mathrm{~s}^{-1}$ and initial distance from the platform was set as $50 \times 10^{-3} \mathrm{~m}$.
LKB probe movement speed was $1 \times 10^{-3} \mathrm{~m} \mathrm{~s}^{-1}$ and initial distance from the platform was set as $25 \times 10^{-}$ ${ }^{3} \mathrm{~m}$. The result for each trial was given as a mean of 5 measurements.

\section{Results and Discussion}

The results of texture, surface color, moisture and oil content of fried carrot slices previously ultrasound assisted pre-dried were given in Table 3.

\subsection{Texture}

As can be seen in Table 3, the hardness values of ultrasound-assisted pre-dried and fried carrot slices were lower than the control group in case of almost all treatments, except for $\mathrm{B}$ and $\mathrm{D}$, but this reduction in the slice hardness was not enormous, instead, limited. Statistical analysis has also supported this fact by indicating that the differences in control and pretreated carrot slices as none significant almost for all cases $(p>0.05)$ (Table 3). In order to analyses the effects of process variables of ultrasound assisted pre-drying, temperature and treatment time were statistically analyzed and the results were given in Table 4 . 
Table 3. Results of texture, color and moisture and oil content of fried carrot slices pretreated by ultrasoundassisted pre-drying

\begin{tabular}{|c|c|c|c|c|c|c|c|}
\hline Groups & $\begin{array}{l}\text { Hardness, } g \\
\text { force }\end{array}$ & Firmness, $\mathrm{g}$ force & $\mathrm{L}^{*}$ & $a^{*}$ & $b^{*}$ & $\begin{array}{c}\text { Moisture } \\
\text { Content, \% }\end{array}$ & $\begin{array}{c}\text { Oil Content, } \\
\%\end{array}$ \\
\hline A & $409.58 \pm 282.57^{\mathrm{a}, \mathrm{b}}$ & $569.95 \pm 227.38^{\mathrm{a}}$ & $53.34 \pm 3.46^{\mathrm{f}}$ & $23.41 \pm 2.91^{\mathrm{c}}$ & $44.55 \pm 4.01^{\mathrm{d}}$ & $51.36 \pm 0.85^{\mathrm{c}, \mathrm{d}}$ & $33.57 \pm 0.58^{\mathrm{c}}$ \\
\hline B & $538.35 \pm 345.76^{\mathrm{a}}$ & $499.41 \pm 188.81^{\mathrm{a}, \mathrm{b}}$ & $56.80 \pm 3.10^{\mathrm{b}, \mathrm{c}}$ & $28.42 \pm 3.00^{\mathrm{b}}$ & $50.64 \pm 3.20^{\mathrm{a}, \mathrm{b}}$ & $58.03 \pm 1.02^{\mathrm{a}, \mathrm{b}}$ & $33.60 \pm 1.58^{c}$ \\
\hline $\mathrm{C}$ & $154.31 \pm 242.74^{\mathrm{b}}$ & $239.01 \pm 143.40^{\mathrm{c}}$ & $54.83 \pm 1.80^{\mathrm{d}, \mathrm{e}}$ & $30.65 \pm 1.92^{\mathrm{a}}$ & $49.89 \pm 2.42^{\mathrm{a}, \mathrm{b}}$ & $47.05 \pm 0.27^{\mathrm{d}, \mathrm{e}, \mathrm{f}}$ & $40.64 \pm 1.80^{\mathrm{b}}$ \\
\hline $\mathrm{D}$ & $485.86 \pm 517.51^{\mathrm{a}, \mathrm{b}}$ & $225.44 \pm 116.68^{\mathrm{c}}$ & $51.19 \pm 2.21^{\mathrm{g}}$ & $31.19 \pm 1.73^{\mathrm{a}}$ & $47.95 \pm 3.91^{\mathrm{c}}$ & $44.19 \pm 6.21^{\mathrm{e}, \mathrm{f}}$ & $34.72 \pm 2.04^{\mathrm{c}}$ \\
\hline E & $141.47 \pm 190.80^{\mathrm{b}}$ & $368.23 \pm 178.03^{\mathrm{a}, \mathrm{b}, \mathrm{c}}$ & $57.35 \pm 3.17^{\mathrm{b}}$ & $24.16 \pm 3.81^{\mathrm{c}}$ & $51.19 \pm 2.24^{\mathrm{a}}$ & $42.00 \pm 0.72^{\mathrm{f}}$ & $47.11 \pm 0.81^{\mathrm{a}}$ \\
\hline $\mathrm{F}$ & $308.15 \pm 183.80^{a, b}$ & $290.04 \pm 142.78^{c}$ & $63.52 \pm 1.36^{\mathrm{a}}$ & $18.64 \pm 3.04^{\mathrm{d}}$ & $49.52 \pm 2.75^{b}$ & $51.29 \pm 1.02^{\mathrm{c}, \mathrm{d}}$ & $39.97 \pm 5.51^{\mathrm{b}}$ \\
\hline G & $410.80 \pm 283.89^{\mathrm{a}, \mathrm{b}}$ & $329.43 \pm 216.45^{\mathrm{b}, \mathrm{c}}$ & $54.34 \pm 1.22^{\mathrm{e}, \mathrm{f}}$ & $28.43 \pm 1.46^{\mathrm{b}}$ & $46.53 \pm 2.03^{c}$ & $53.47 \pm 2.72^{\mathrm{b}, \mathrm{c}}$ & $34.44 \pm 1.67^{\mathrm{c}}$ \\
\hline $\mathrm{H}$ & $358.49 \pm 416.32^{\mathrm{a}, \mathrm{b}}$ & $511.17 \pm 275.01^{\mathrm{a}, \mathrm{b}}$ & $55.65 \pm 1.30^{\mathrm{c}, \mathrm{d}}$ & $28.59 \pm 1.55^{\mathrm{b}}$ & $47.40 \pm 2.78^{c}$ & $46.67 \pm 2.11^{\mathrm{d}, \mathrm{e}, \mathrm{f}}$ & $36.22 \pm 0.83^{\mathrm{b}, \mathrm{c}}$ \\
\hline I & $181.29 \pm 222.14^{\mathrm{b}}$ & $542.60 \pm 188.97^{\mathrm{a}}$ & $57.64 \pm 1.16^{\mathrm{b}}$ & $30.61 \pm 1.35^{\mathrm{a}}$ & $47.67 \pm 1.38^{\mathrm{c}}$ & $59.72 \pm 0.43^{\mathrm{a}}$ & $32.19 \pm 0.06^{\mathrm{c}}$ \\
\hline Control & $462.75 \pm 443.18^{\mathrm{a}, \mathrm{b}}$ & $549.02 \pm 231.48^{\mathrm{a}}$ & $50.25 \pm 2.86^{\mathrm{g}}$ & $30.35 \pm 1.43^{\mathrm{a}}$ & $41.76 \pm 3.21^{\mathrm{e}}$ & $48.00 \pm 0.70^{\mathrm{c}, \mathrm{d}, \mathrm{e}}$ & $32.50 \pm 1.35^{\mathrm{c}}$ \\
\hline
\end{tabular}

Different letters in the same column indicate a significant difference $(p \leq 0.05)$

Table 4. Effects of temperatures and time of the ultrasound assisted pre-drying on the hardness of fried carrot slices

\begin{tabular}{lccc}
\hline $\begin{array}{l}\text { Hardness } \\
\text { (g, force) }\end{array}$ & \multicolumn{2}{c}{ Temperature $\left({ }^{\circ} \mathrm{C}\right)$} \\
\hline \multirow{2}{*}{ Time } & 5 & $409.58 \pm 282.57^{\mathrm{A}, \mathrm{a}, \mathrm{b}}$ & $485.86 \pm 517.51^{\mathrm{A}, \mathrm{a}}$ \\
$(\mathrm{min})$ & 10 & $538.35 \pm 345.76^{\mathrm{A}, \mathrm{a}}$ & $141.47 \pm 190.80^{\mathrm{B}, \mathrm{b}}$ \\
& 15 & $154.31 \pm 242.74^{\mathrm{A}, \mathrm{b}}$ & $308.15 \pm 183.80^{\mathrm{A}, \mathrm{a}, \mathrm{b}}$ \\
\hline
\end{tabular}

Different capital letters in the same row indicate a significant difference in terms of application temperatures $(p \leq 0.05)$ Different lowercase letters in the same column indicate a significant difference in terms of application time $(p \leq 0.05)$

The difference among the application time of the ultrasonic pre-treatment carried out for 10 and 15 minutes at $30^{\circ} \mathrm{C}$ were significant $(p \leq 0.05)$. Hardness of carrot slices were only changed with temperature rise from $30^{\circ} \mathrm{C}$ to $50^{\circ} \mathrm{C}$, when the ultrasound assisted pre-drying was performed for 10 min (Table 4).

Similar to the hardness values of carrot slices, it was seen that treatments C, D, F, and G caused significant changes in firmness value compared to that of control group $(p \leq 0.05)$. Remaining ones were found to be statistically same as control (Table 3). Change in firmness of fried carrot slices depending on the process conditions of pre-dried by ultrasound assisted drying technique were displayed in Table 5. The influence of temperature increasing from $30{ }^{\circ} \mathrm{C}$ to $50{ }^{\circ} \mathrm{C}$ was only found to be significant when pretreatment was applied for 5 min $(p \leq 0.05)$. Treatment time caused any significant change in firmness of carrot slices, when it was performed at $10 \mathrm{~min}$ and $15 \mathrm{~min}$ $(p>0.05)$. For both temperature levels, it was seen that the firmness decreased with increasing time (Table 5).
Table 5. Effects of temperatures and time of the ultrasound assisted pre-drying on the firmness of fried carrot slices

\begin{tabular}{lccc}
\hline $\begin{array}{l}\text { Firmness } \\
\text { (g. force) }\end{array}$ & \multicolumn{2}{c}{ Temperature $\left({ }^{\circ} \mathrm{C}\right)$} \\
\hline \multirow{2}{*}{ Time } & 5 & $569.95 \pm 227.38^{\mathrm{A}, \mathrm{a}}$ & $225.44 \pm 116.68^{\mathrm{B}, \mathrm{b}}$ \\
$(\min )$ & 10 & $499.41 \pm 188.81^{\mathrm{A}, \mathrm{a}}$ & $368.23 \pm 178.03^{\mathrm{A}, \mathrm{a}}$ \\
& 15 & $239.01 \pm 143.40^{\mathrm{A}, \mathrm{b}}$ & $290.04 \pm 142.78^{\mathrm{A}, \mathrm{a}, \mathrm{b}}$ \\
\hline
\end{tabular}

Different capital letters in the same row indicate a significant difference in terms of application temperatures $(p \leq 0.05)$. Different lowercase letters in the same column indicate a significant difference in terms of application time $(p \leq 0.05)$

Table 6. The effects different intensity ultrasound power on textural properties of fried carrot slices

\begin{tabular}{cccc}
\hline Experiments & $\begin{array}{c}\text { Power } \\
(\%)\end{array}$ & $\begin{array}{c}\text { Hardness, g } \\
\text { force }\end{array}$ & $\begin{array}{c}\text { Firmness, g } \\
\text { force }\end{array}$ \\
\hline $\mathrm{G}$ & 30 & $410.80 \pm 283.89^{\mathrm{a}}$ & $329.43 \pm 216.45^{\mathrm{a}}$ \\
$\mathrm{H}$ & 50 & $358.49 \pm 416.32^{\mathrm{a}}$ & $511.17 \pm 275.01^{\mathrm{a}}$ \\
$\mathrm{I}$ & 70 & $181.29 \pm 222.14^{\mathrm{a}}$ & $542.60 \pm 188.97^{\mathrm{a}}$ \\
\hline
\end{tabular}

Different letters in the same column indicate a significant difference $(p \leq 0.05)$

According to the results given in Table 6, it is seen that there is no any significant change in hardness or firmness values of fried carrot slices with changing ultrasound power $(p>0.05)$. Brncic et al. (2010) studied the ultrasound assisted drying at different ultrasound power and reported the absence of significant effect on the textural properties or a limited effect. In another study conducted by Dujmić et al. (2013), increasing ultrasound power was found to cause a decrease in hardness values but noted that this effect was not statistically significant. These results are coincidence with the finding in this current study. 


\subsection{Surface Color Values}

As can be seen in Table 3, $\mathrm{L}^{*}$ values, representing surface brightness of fried carrot slices pre-dried by ultrasound assisted drying technique, displayed that the nearest brightness value to control group was achieved for the carrot slices processed at the conditions coded as D among all experiments. Besides to D group, $\mathrm{L}^{*}$ values of remaining ones are shown to be higher than control group (Table 3 ). Color change from green to red is defined with $\mathrm{a}^{*}$ value. The results indicated that the general trend in $\mathrm{a}^{*}$ value was a decrease compared to control group $(p \leq 0.05)$, but few exceptions being coded treatments of C, D, and I ( $p>0.05)$. $\mathrm{b}^{*}$ value is another surface color parameter measured in current study. Table 3 shows that compared to $b^{*}$ value of control group, there is an increase in this color parameter of fried carrot slices if they were pretreated by ultrasound assisted drying technique before frying $(p \leq 0.05)$. Ultrasound parameters (temperature and time) were also investigated to figure out their influences on $\mathrm{L}^{*}, \mathrm{a}^{*}$ and $\mathrm{b}^{*}$ values. Figure 1, Figure 2 and Figure 3 display the change in surface color parameters with temperature and time as well as their statistical differences. It is seen that at constant temperature level, increasing sonication time caused an increase in $\mathrm{L}^{*}$ value and this is more apparent when medium temperature was $50^{\circ} \mathrm{C}$ (Figure 1). The temperature was found not to create any certain effect on $\mathrm{L}^{*}$ value of fried carrot slices as seen from Figure 1. For $5 \mathrm{~min}$ treatment, as changing temperature value from $30^{\circ} \mathrm{C}$ to $50^{\circ} \mathrm{C}$ lowered the $\mathrm{L}^{*}$ value. On the other hand, an increase in brightness was seen with increasing temperature, when sonication was 15 min (Figure 1). No statistically significant change was observed with temperature for $10 \mathrm{~min}$ treatment. The temperature significantly affected $\mathrm{a}^{*}$ value for all treatment durations $(p \leq 0.05)$, but this effect was different in between $5 \mathrm{~min}$ and 10 or 15 min treatments. There was an increase in $\mathrm{a}^{*}$ value for $5 \mathrm{~min}$ treatment, whereas $\mathrm{a}^{*}$ value decreased for the treatments of $10 \mathrm{~min}$ and $15 \mathrm{~min}$ (Figure 2). This may be related to the effect of temperature-time on carotenoid content of carrot slices. Because, for short term application, carotenoids may turn to free form with effects of temperature and ultrasound, but further increase in process time resulted in adverse effect of temperature like that was seen for treatments of 10 min and 15 min and carotenoids degraded and $\mathrm{a}^{*}$ value partially decreased. As can be seen from Figure 2 that an increase in $a^{*}$ value was seen with increasing sonication time from $5 \mathrm{~min}$ to $15 \mathrm{~min}$ at $30^{\circ} \mathrm{C}$, but this influence was reversed and increasing process time caused a decrease for sonication processes carried at $50^{\circ} \mathrm{C}$. Another color parameter $\mathrm{b}^{*}$ was also studied and temperature and process time were found to affect it in limited extent (Figure 3). Except for $5 \mathrm{~min}$ treatment $(p \leq 0.05), \mathrm{b}^{*}$ value did not change with temperature $(p>0.05)$. There was also no change in $\mathrm{b}^{*}$ value with time when sonication was at $30^{\circ} \mathrm{C}$. However, time affected $\mathrm{b}^{*}$ value $(p \leq 0.05)$ when sonication temperature was increased to $50^{\circ} \mathrm{C}$, but this effect did not have a clear trend, instead fluctuated.

Ultrasound power was another process variable controlled in this study and the effect of its change was investigated in terms of surface color. The results were shown in Figure 4. An increase in ultrasound power was seen to increase brightness ( $\mathrm{L}^{*}$ value) and redness ( $\mathrm{a}^{*}$ value) of carrot slices $(p \leq 0.05)$, but no significant change in $\mathrm{b}^{*}$ value was detected $(p>0.05)$ (Figure 4$)$. An increase in $L^{*}$ value was continued throughout the power levels. Power change was effective for $\mathrm{a}^{*}$ value after it was shifted from $30 \%$ to $70 \%(p \leq 0.05)$, there was no difference between $a^{*}$ values measured for samples processed at $30 \%$ and $50 \%$ power levels $(p>0.05)$ (Figure 4). The change in color may be attributed to the cavitation occurred as a result of ultrasound. Tiwari et al. (2008) have reported change in color parameters after ultrasound application and they have associated these changes with the effects of ultrasound. An intensification in $a^{*}$ value may also be attributed to the isomerization of carotenoids and reduction in degradation of $\beta$-carotene (Chen et al., 1995; Sun et al., 2010). 


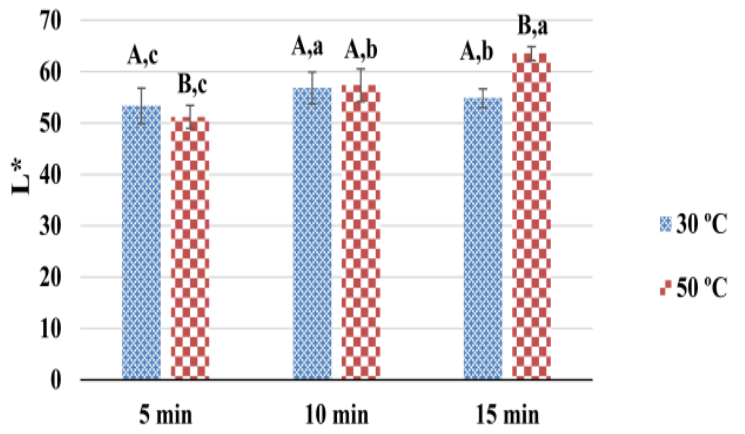

Figure 1. Effects of temperatures and time of the ultrasound assisted pre-drying on the brightness of fried carrot slices

Different lowercase letters indicate a significant difference in terms of ultrasound application time separately for each temperature $(p \leq 0.05)$

Different capital letters in the per column indicate a significant difference in terms of application temperatures for each time $(p \leq 0.05)$

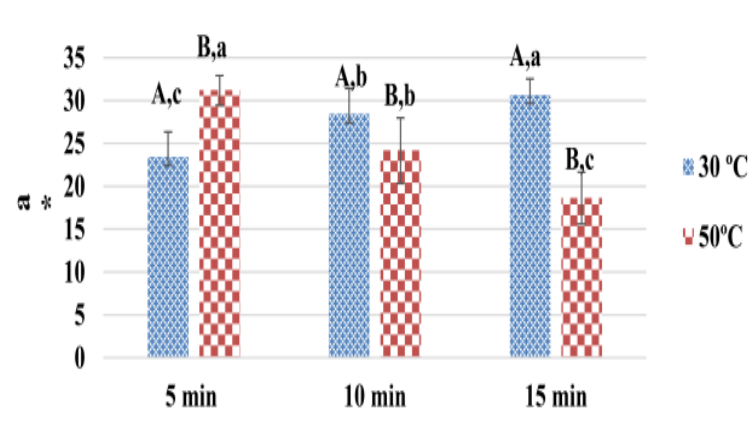

Figure 2. Effects of temperatures and time of the ultrasound assisted pre-drying on the $\mathrm{a}^{*}$ values of fried carrot slices

Different lowercase letters indicate a significant difference in terms of ultrasound application time separately for each temperature $(p \leq 0.05)$

Different capital letters in the per column indicate a significant difference in terms of application temperatures for each time $(p \leq 0.05)$

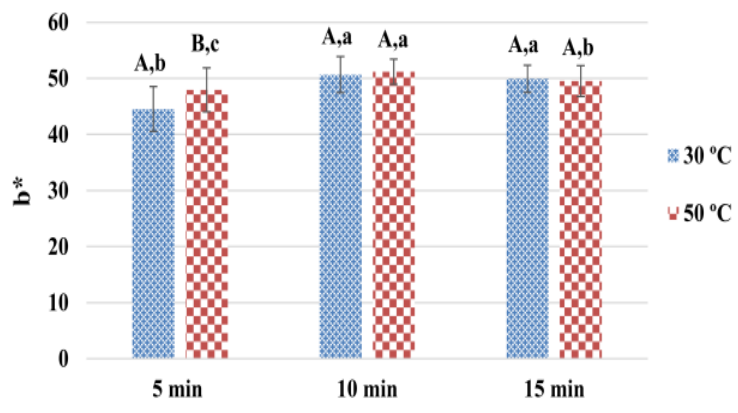

Figure 3. Effects of temperatures and time of the ultrasound assisted pre-drying on the $b^{*}$ values of fried carrot slices

Different lowercase letters indicate a significant difference in terms of ultrasound application time separately for each temperature $(p \leq 0.05)$

Different capital letters in the per column indicate a significant difference in terms of application temperatures for each time $(p \leq 0.05)$
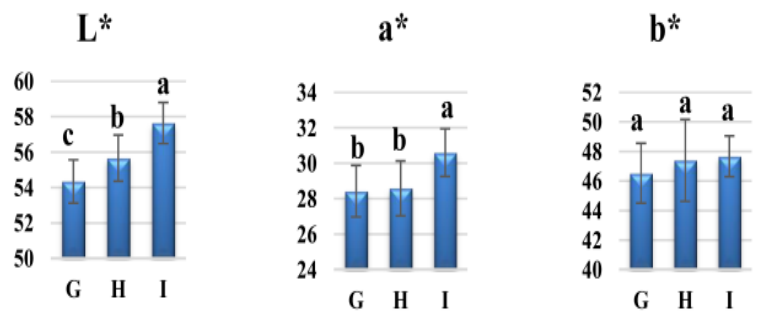

Figure 4. The effects of ultrasound power on surface color of fried carrot slices

Different letters indicate a significant difference for each color parameters separately $(p \leq 0.05)$

\subsection{Moisture Content}

Compared to control group, the moisture content of fried carrot slices differed depending on the conditions of ultrasound applications $(p \leq 0.05)$ (Table 3). Change in moisture content of final product occurred as a decrease or an increase. Thus, the influence of sonication conditions on moisture content of fried carrots was also investigated and temperature and time effects were analyzed in Table 7. 
Table 7. Effects of temperatures and time of the ultrasound assisted pre-drying on the moisture content of fried carrot slices

\begin{tabular}{cccc}
\hline \multicolumn{2}{c}{ Moisture } & \multicolumn{2}{c}{ Temperature $\left({ }^{\circ} \mathrm{C}\right)$} \\
\multicolumn{2}{c}{ Content $(\%)$} & 30 & 50 \\
\hline \multirow{2}{*}{ Time } & 5 & $51.36 \pm 0.85^{\mathrm{A}, \mathrm{b}}$ & $44.19 \pm 6.21^{\mathrm{A}, \mathrm{a}}$ \\
$(\mathrm{min})$ & 10 & $58.03 \pm 1.02^{\mathrm{A}, \mathrm{a}}$ & $42.00 \pm 0.72^{\mathrm{B}, \mathrm{a}}$ \\
& 15 & $47.05 \pm 0.27^{\mathrm{A}, \mathrm{c}}$ & $51.29 \pm 1.02^{\mathrm{B}, \mathrm{a}}$ \\
\hline
\end{tabular}

Different capital letters in the same row indicate a significant difference in terms of application temperatures $(p \leq 0.05)$

Different lowercase letters in the same column indicate a significant difference in terms of application time $(p \leq 0.05)$

Tabulated results indicated that temperature elevation was only effective on moisture content, when application time was higher than 10 minutes $(p \leq 0.05)$, in other words there was no change in moisture content with sonication temperature for 5 min- treatment $(p>0.05)$. Process time was also considered and it was found to cause a change in moisture content only application temperature was $30^{\circ} \mathrm{C} \quad(p \leq 0.05)$. Although moisture content increased especially after treatment time of $10 \mathrm{~min}$, this change did not occur at significant level when sonication was conducted at the temperature level of $50^{\circ} \mathrm{C}$. The last parameter of ultrasound application was power level and the influence of different sonication power in the fix time and temperature applications was shown in Figure 5. A decrease in moisture content at certain level was seen with increasing ultrasound power from $30 \%$ to $50 \%$, but further increase up to $70 \%$ caused an increase in moisture content again. This variation in moisture content under the effect of power level was found to be statistically significant $(p \leq 0.05)$. Gallego-Juárez et al. (2007) reported that increasing the ultrasonic power raised the diffusion coefficient and accordingly it was supposed that the amount of moisture away from the product was increased by rising the ultrasound power. In this study similar effect was seen for power level of $30 \%$ and $50 \%$ and this effect was thought to be relevant to the occurrence of micro channels in solid matrix and thus moisture level decreased. However, at $70 \%$ power there was an increase in moisture content. This increase occurring in moisture content of product was attributed to the failure to remove moisture from the structure due to the collapses in the micro channel with the high ultrasonic effect, at 70\% level (Figure 5).

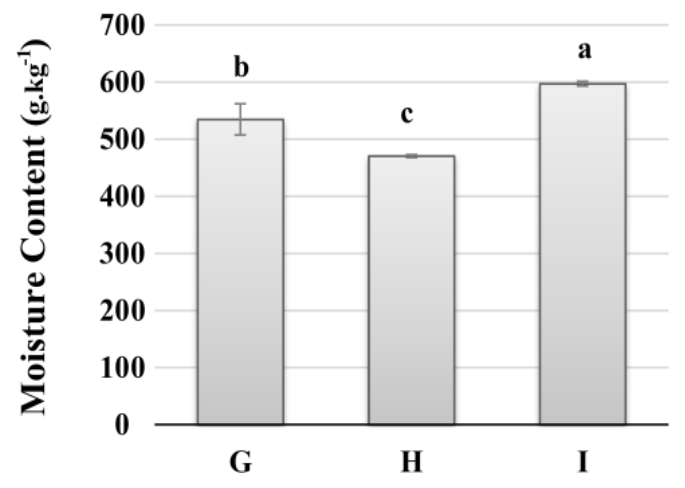

Figure 5. The effects different intensity ultrasound power on moisture content of fried carrot slices Different letters indicate a significant difference $(p \leq 0.05)$

\subsection{Oil Content}

Oil content of ultrasound assisted dried and fried carrot slices were tabulated in Table 3. Oil content of final fried carrot slices were generally higher than that measured for control group samples $(p \leq 0.05)$. This may be explained with the effects of ultrasound on structure of carrot slices, since the cavitation occurred as a result of sonication caused mechanical effects on layers close to surface and this accelerates the mass transfer throughout/ into the solid matrix. Thus, oil absorption increased during frying as well that occurred for moisture transfer out of solid. Temperature and time effects on oil absorption of fried carrot slices were given in Table 8 where it was seen that both variables caused significant changes in oil content $(p \leq 0.05)$. At constant temperature level, in general manner, an increase in process time resulted in an increase in oil content. Temperature change was found only to affect oil content for $10 \mathrm{~min}$ treatment (Table 8).

Table 8. Effects of temperatures and time of the ultrasound assisted pre-drying on the oil content of fried carrot slices

\begin{tabular}{cccc}
\hline \multirow{2}{*}{ Oil Content } & \multicolumn{2}{c}{ Temperature $\left({ }^{\circ} \mathrm{C}\right)$} \\
& 5 & 30 & 50 \\
\hline \multirow{2}{*}{ Time } & $53.57 \pm 0.58^{\mathrm{A}, \mathrm{b}}$ & $34.72 \pm 2.0^{\mathrm{A}, \mathrm{b}}$ \\
$($ min $)$ & 10 & $33.60 \pm 1.58^{\mathrm{A}, \mathrm{b}}$ & $47.11 \pm 0.81^{\mathrm{B}, \mathrm{a}}$ \\
& 15 & $40.64 \pm 1.80^{\mathrm{A}, \mathrm{a}}$ & $39.97 \pm 5.51^{\mathrm{A}, \mathrm{a}, \mathrm{b}}$ \\
\hline
\end{tabular}

Different capital letters in the same row indicate a significant difference in terms of application temperatures $(p \leq 0.05)$

Different lowercase letters in the same column indicate a significant difference in terms of application time $(p \leq 0.05)$

Power level of sonication was another variable and its effect on oil content of fried carrot slices were seen in Figure 6. Increased power level of 
sonication was found to create statistically significant difference for $50 \%$ power level compared to $30 \%$ and $70 \%$ power levels (Figure 6). When oil absorption was taken into account, it was compatible with that observed for moisture content change in general trend (Figure 6).

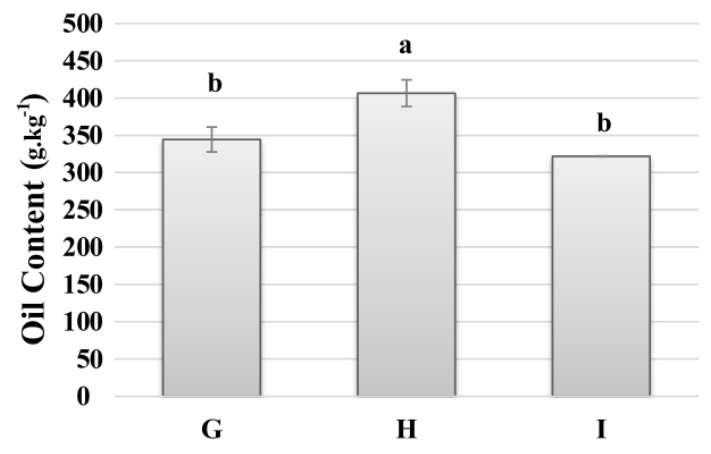

Figure 6. The effects different intensity ultrasound power on oil content of fried carrot slices Different letters indicate a significant difference $(p \leq 0.05)$

\section{Conclusion}

The effect of ultrasound applied during drying was found not to change the oil absorption in the studied conditions. However, there are some differences in other investigated properties including color. As a result, although ultrasound application in drying have been reported to provide some changes in drying characteristics being relevant to the textural variations, these changes were not enough to affect the oil absorption taking place during frying process being contrast to expectations. Briefly, it could be said that further studies including different process conditions are required to evaluate the effect of ultrasound application on oil absorption.

\section{Acknowledgement}

This work was supported by Süleyman Demirel University Scientific Research Projects Coordination Unit (grant number 4207-YL1-14); and The Scientific and Technological Research Council of Turkey (grant number 113R015).

\section{References}

Brncic M., Karlovic S., Rimac B.S., Bosiljkov T., Ježek D., Tripalo B. (2010). Textural properties of infra red dried apple slices as affected by high power ultrasound pre- treatment. African Journal of Biotechnology, 9(41), 6907-6915.

Chen B.H., Peng H.Y., Chen H.E. (1995). Changes of Carotenoids, Color, and Vitamin A Contents during Processing of Carrot Juice. Journal of Agricultural and Food Chemistry, 43(7), 1912-1918.

Dueik V., Robert P., Bouchon P. (2010). Vacuum frying reduces oil uptake and improves the quality parameters of carrot crisps. Food Chemistry, 119(3), 1143-1149.

Dujmić F., Brnčić M., Karlović S., Bosiljkov T., Ježek D., Tripalo B., Mofardin I. (2013). Ultrasound- Assisted Infrared Drying of Pear Slices: Textural Issues. Journal of Food Process Engineering, 36(3), 397-406.

Esturk O., Kayacier A., Singh R.K. (2000). Reduction of oil uptake in deep fried tortilla chips Reducción de la absorción de aceite en la fritura de tiras de maíz. Revista de Agroquimica y Tecnologia de Alimentos, 6(5), 425-431.

Fan L.-p., Zhang M., Mujumdar A.S. (2005). Vacuum frying of carrot chips. Drying Technology, 23(3), 645-656.

Fernandes F.A., Rodrigues S., Gaspareto O.C., Oliveira E.L. (2006). Optimization of osmotic dehydration of bananas followed by air-drying. Journal of Food Engineering, 77(1), 188-193.

Gallego-Juárez J.A., Riera E., De la Fuente Blanco S., Rodríguez-Corral G., Acosta-Aparicio V.M., Blanco A. (2007). Application of high-power ultrasound for dehydration of vegetables: processes and devices. Drying Technology, 25(11), 1893-1901.

Gamble M., Rice P. (1987). Effect of pre- fry drying of oil uptake and distribution in potato crisp manufacture. International Journal of Food Science \& Technology, 22(5), 535-548.

Garcia-Perez J., Cárcel J., Benedito J., Mulet A. (2007). Power ultrasound mass transfer enhancement in food drying. Food and Bioproducts Processing, 85(3), 247-254.

García M.A., Ferrero C., Campana A., Bértola N., Martino M., Zaritzky N. (2004). Methylcellulose Coatings Applied to Reduce Oil Uptake in Fried Products. Revista de Agroquimica y Tecnologia de Alimentos, 10(5), 339-346. 
Gichuhi P., Mortley D., Bromfield E., BovellBenjamin A. (2009). Nutritional, physical, and sensory evaluation of hydroponic carrots (Daucus carota L.) from different nutrient delivery systems. Journal of Food Science, 74(9), S403-S412.

Gupta, M.K. (2005). Frying Oils.

Ikoko J., Kuri V. (2007). Osmotic pre-treatment effect on fat intake reduction and eating quality of deep-fried plantain. Food Chemistry, 102(2), 523-531.

James C.S. (1998). Analytical Chemistry Of Foods. James C.S. (Ed.) Springer.

Karacabey E., Turan M.S., Özçelik Ş.G., Baltacıoğlu C., Küçüköner E. (2016). Optimisation of pre- drying and deep- fatfrying conditions for production of low- fat fried carrot slices. Journal of the Science of Food and Agriculture.

Krokida M., Oreopoulou V., Maroulis Z., MarinosKouris D. (2001). Deep fat frying of potato strips - quality issues. Drying Technology, 19(5), 879-935.

Lalam S., Sandhu J.S., Takhar P.S., Thompson L.D., Alvarado C. (2013). Experimental study on transport mechanisms during deep fat frying of chicken nuggets. LWT-Food Science and Technology, 50(1), 110-119.

Lamberg I., Hallstroem B., Olsson H. (1990). Fat uptake in a potato drying/frying process. Lebensmittel Wissenschaft und Technologie, 23(4), 295-300.

Medina M., Antequera T., Ruiz J., Jiménez-Martín E., Pérez-Palacios T. (2015). Quality characteristics of fried lamb nuggets from low-value meat cuts: Effect of formulation and freezing storage. Revista de Agroquimica y Tecnologia de Alimentos, 21(7), 503-511.

Moreira R.G., Castell-Perez M.E., Barrufet M.A. (1999). Deep fat frying: Fundamentals and applications.

Moreira R.G., Sun X., Chen Y. (1997). Factors affecting oil uptake in tortilla chips in deepfat frying. Journal of Food Engineering, 31(4), 485-498.

Nowacka M., Wiktor A., Śledź M., Jurek N., Witrowa-Rajchert D. (2012). Drying of ultrasound pretreated apple and its selected physical properties. Journal of Food Engineering, 113(3), 427-433.

Ortuño C., Pérez-Munuera I., Puig A., Riera E., Garcia-Perez J. (2010). Influence of power ultrasound application on mass transport and microstructure of orange peel during hot air drying. Physics Procedia, 3(1), 153159.

Pedreschi F., Moyano P. (2005). Effect of predrying on texture and oil uptake of potato chips. LWT - Food Science and Technology, 38(6), 599-604.

Robertson A.R. (1977). The CIE 1976 ColorDifference Formulae. Color Research and Application, 2(1), 7-11.

Saguy I.S., Dana D. (2003). Integrated approach to deep fat frying: engineering, nutrition, health and consumer aspects. Journal of Food Engineering, 56(2), 143-152.

Song X.-j., Zhang M., Mujumdar A.S. (2007). Optimization of vacuum microwave predrying and vacuum frying conditions to produce fried potato chips. Drying Technology, 25(12), 2027-2034.

Sulaeman A., Keeler L., Giraud D., Taylor S.L., Wehling R., Driskell J. (2001). Carotenoid Content and Physicochemical and Sensory Characteristics of Carrot Chips Deep- Fried in Different Oils at Several Temperatures. Journal of Food Science, 66(9), 1257-1264.

Sun Y., Ma G., Ye X., Kakuda Y., Meng R. (2010). Stability of all-trans- $\beta$-carotene under ultrasound treatment in a model system: Effects of different factors, kinetics and newly formed compounds. Ultrasonics Sonochemistry, 17(4), 654-661.

Tiwari B., Muthukumarappan K., O'donnell C., Cullen P. (2008). Colour degradation and quality parameters of sonicated orange juice using response surface methodology. LWTFood Science and Technology, 41(10), 1876-1883.

Vitrac O. (2000). Caractérisation expérimentale et modélisation de l'opération de friture. (Doctoral dissertation, Massy, ENSIA). 